\title{
Barriers to fistula repair in Uganda: A formative study
}

Population Council

Follow this and additional works at: https://knowledgecommons.popcouncil.org/departments_sbsr-rh

Part of the Demography, Population, and Ecology Commons, Family, Life Course, and Society

Commons, International Public Health Commons, Maternal and Child Health Commons, and the Women's Health Commons

How does access to this work benefit you? Let us know!

\section{Recommended Citation}

"Barriers to fistula repair in Uganda: A formative study," brief. Washington, DC: Population Council, 2016. 


\section{BARRIERS TO FISTULA REPAIR IN UGANDA: A FORMATIVE STUDY}

\section{INTRODUCTION}

Obstetric fistula is a preventable and treatable maternal morbidity condition, which occurs in some low-income countries, caused by prolonged obstructed labor that results in a hole between the vagina and the bladder or rectum through which urine or feces leak. Unrepaired fistula can lead to lifelong ostracism, stigma, and shame.

A formative research study was conducted in Uganda, building on upon the results of a systematic review (see side panel) to better understand the barriers and enabling factors for fistula repair care delivery and access. Understanding how Ugandan women living with fistula decide to seek care, identify and reach medical centers, and receive adequate and appropriate care is integral and continues to influence the design of a larger implementation pilot. This study focuses on Fistula Care Plus project-supported treatment facilities where fistula camps are routinely held.

\section{METHODOLOGY}

Seventy-three in-depth interviews (IDIs) and eight focus group discussions (FGDs) were conducted in Hoima and Masaka, in and around Hoima Regional Referral Hospital and Kitovu Mission Hospital, respectively, from October to December 2015. The data captured a range of perspectives from those with personal or professional fistula experience, for both individual and group narratives of the experiences of those affected by fistula in Uganda.

\section{TABLE 1: SAMPLE BREAKDOWN}

\section{SYSTEMATIC REVIEW}

To identify and understand the delays in accessing and receiving treatment and corresponding barriers, document interventions that help to overcome barriers, and to specify gaps in the literature that require further research, we conducted a systematic review of peer-reviewed and grey literature.

Based on the frequency of barrier themes noted in the included articles, nine categories of barriers were identified.
- Psychosocial
- Cultural
- Awareness
- Social
- Financial
- Transportation
- Facility shortages
- Quality of care
- Political

The studies mentioning each of these nine barriers were tallied and the Thaddeus and Maine's (1994) Three Delays Model provided theoretical guidance to classify the barriers to accessing obstetric fistula care.

\begin{tabular}{|c|c|c|c|}
\hline & Hoima & Masaka & Total \\
\hline IDIs & 40 & 33 & 73 \\
\hline Women affected by fistula & 20 & 15 & 32 \\
\hline Spouses and other accompanying family members & 6 & 5 & 11 \\
\hline Providers at camps & 10 & 10 & 20 \\
\hline Facility and district managers & 4 & 3 & 7 \\
\hline FGDs & 4 & 4 & 8 \\
\hline Post-repair clients & 2 & 2 & 4 \\
\hline Community stakeholders -women & 1 & 1 & 2 \\
\hline Community stakeholders -men & 1 & 1 & 2 \\
\hline Total & & & 80 \\
\hline
\end{tabular}




\section{KEY FINDINGS}

Prevailing views indicate that barriers and enablers of access to fistula repair care are clustered around awareness, psychosocial, cultural, social, financial, transportation, facility shortages, quality of care, policy and political environment, and healing and reintegration factors (listed below), which influence, in distinct as well as reinforcing ways, the delay to seek care, delay in reaching care, and delay in receiving care once at a hospital. The nuances within each of these categories reveal cross-cutting challenges such as poverty, limited education, gender dynamics, social norms, and political structures affecting fistula prevention and treatment.

\section{CONCLUSION}

Evidence supports findings from the systematic review and highlights the importance of women's healing and reintegration into the community. Determinants of care affect each other and access to repair in direct and indirect ways. Related and cross-cutting barriers often involve poverty, early marriage and limited education, gender dynamics within households and communities, and women's agency for making choices about their reproductive health. Though it is difficult to measure the relative influence of each barrier and enabler, awareness, financial, and transport issues consistently emerge as areas to target for policy and programming.

\section{TABLE 2: BARRIERS AND ENABLERS OF FISTULA REPAIR}

\begin{tabular}{|c|c|c|}
\hline Domains & Barriers & Enablers \\
\hline Awareness & $\begin{array}{l}\text { "Some people say the disease is hereditary and it } \\
\text { came from their grandmothers..." } \\
\qquad \text {-Fistula client, pre-repair }\end{array}$ & $\begin{array}{l}\text { "When the trainings started, we became aware. [...] the } \\
\text { whole village knowing you are the one leaking urine is } \\
\text { good, but l emphasize removing fear so that they come to } \\
\text { the health facility." } \\
\text {-Community woman }\end{array}$ \\
\hline Cultural & $\begin{array}{c}\text { "If a person isn't taught how fistula happens, she will } \\
\text { think the co-wife is the one bewitching her..." } \\
\text {-Nurse-counselor }\end{array}$ & $\begin{array}{l}\text { "What is done here [for camps] is radio announcements } \\
\text { that reach very far. When [some]one hears and she } \\
\text { knows somebody, a friend or relative, who has this } \\
\text { condition, these people also again call. They call those } \\
\text { that are very far; where the radios don't reach" } \\
\text {-ANC/Maternity Unit staff }\end{array}$ \\
\hline Psychosocial & $\begin{array}{l}\text { "I used to cry all the time, I spent four years crying } \\
\text { and bearing in mind that my sister was mistreating } \\
\text { me... I refused to eat but I didn't reach an extent of } \\
\text { killing or poisoning myself." } \\
\text {-Fistula client, post-repair }\end{array}$ & $\begin{array}{l}\text { "They should give encouragement and counseling, } \\
\text { showing that they aren't the only one with [fistula] in the } \\
\text { whole world. They shouldn't [...] stigmatize us like when } \\
\text { you pass them they put fingers on their noses." } \\
\text {-Fistula client, post-repair }\end{array}$ \\
\hline Social & $\begin{array}{l}\text { "They get disgusted [with] you; your husband gets } \\
\text { disgusted, the community members, once they know, } \\
\text { get disgusted and say you smell, that you're } \\
\text { leaking... Even [family members], it's the same, they } \\
\text { gossip." } \\
\text {-Fistula client, living with Fistula }\end{array}$ & $\begin{array}{c}\text { "Even my maternal relatives know, in fact many people } \\
\text { now know about it... they treated me well, they didn't } \\
\text { segregate me at all. In fact they took care of me." } \\
\qquad \text {-Fistula client, post-repair }\end{array}$ \\
\hline $\begin{array}{c}\text { Financial/ } \\
\text { Transportation }\end{array}$ & $\begin{array}{l}\text { "You may find a woman at home with no money } \\
\text { because as a man, you earn so little so you leave } \\
\text { little...some stay very far in villages and so may } \\
\text { choose to stay at home." } \\
\text {-Community Man }\end{array}$ & $\begin{array}{l}\text { "My husband paid for our transport, we had grown beans } \\
\text { which we sold and later got money. We first paid off all } \\
\text { the debts we had. We used the little balance to come } \\
\text { here. After the little [bit] of money was finished, we } \\
\text { started borrowing from friends and that's how we are } \\
\text { surviving." } \\
\text {-fistula client, pre-repair }\end{array}$ \\
\hline $\begin{array}{c}\text { Facility shortages/ } \\
\text { Quality of care }\end{array}$ & $\begin{array}{l}\text { "Health workers around our health centers here are } \\
\text { very few. You find them overwhelmed and really tired } \\
\text { remember they get very little money as salary so they } \\
\text { end up frustrated and replying you any how they } \\
\text { wish." } \\
\text {-Community Man }\end{array}$ & $\begin{array}{l}\text { "That is holistic care, the care that we give them included } \\
\text { all the physiological, social, and physical." } \\
\text {-Nurse-counselor }\end{array}$ \\
\hline $\begin{array}{c}\text { Policy \& political } \\
\text { environment }\end{array}$ & $\begin{array}{l}\text { "At the district we have no ambulances. We lack } \\
\text { enough qualified staff at the facility. Within the health } \\
\text { system, transportation is still lacking, the health } \\
\text { workers need training and we also need to sensitize } \\
\text { our communities." } \\
\text {-District level manager }\end{array}$ & $\begin{array}{l}\text { "...they should give us support like they help [people with } \\
\text { disabilities] because we are also unable to do work, that } \\
\text { is also a disability and so we need support... We also need } \\
\text { financial support especially when our husbands do not } \\
\text { care about us, we need to survive." } \\
\text { fistula client, pre-repair }\end{array}$ \\
\hline $\begin{array}{l}\text { Healing and } \\
\text { Reintegration }\end{array}$ & $\begin{array}{c}\text { "You can be repaired, but it is not a guarantee that } \\
\text { you will be fixed - like me I have been repaired for six } \\
\text { times, but up to now it has so far refused." } \\
\text {-Fistula client, pre-repair }\end{array}$ & $\begin{array}{l}\text { "The counselors after the operation are supposed to link } \\
\text { them to community groups that aid them to go back to } \\
\text { the community safely." } \\
\text {-Head matron }\end{array}$ \\
\hline
\end{tabular}

